\title{
THE IMPACT OF QUERCETIN ON THE FUNCTIONAL STATE OF CARDIOVASCULAR SYSTEM AND HEMOSTASE IN RATS WITH TYPE 2 DIABETES MELLITUS*
}

\author{
Ivanova $\mathbf{O}$. V. \\ SI «V. Danilevsky Institute for Endocrine Pathology Problems of the NAMS of Ukraine», \\ Kharkiv, Ukraine \\ ivolga3006@ukr.net
}

Type 2 diabetes mellitus (T2DM) has become a major global public health issue in the twenty-first century and its incidence has increased each year. Cardiovascular disease (CVD) remains the main cause of morbidity and mortality in patients with T2DM and approximately three quarters of patients die due to CVD complications [1].

Type 2 diabetes mellitus is associated with the development of diabetic cardiomyopathy (DCM). DCM is characterized by lipid accumulation in cardiomyocytes, fibrosis and left ventricular hypertrophy, which together result in contractile dysfunction. The development DCM is likely to be multifactorial and several pathways have been known, including vascular endothelial dysfunction, glucose toxicity, mitochondrial dysfunction and lipotoxicity [2].

In addition, T2DM is associated with inflammatory and prothrombotic states, which aggravate the development of atherothrombosis [3]. Clot formation and function are directly affected by insulin resistance and hyperglycaemia, which resulted in increasing levels of procoagulation factors and antifibrinolytic proteins and more resistant to lysis fibrin network, coupled with increased platelet activation [4].

Several mechanisms are suggested to explain the platelet dysfunction in DM patients [5], including oxidative stress.

It is known that oxidative stress induces endothelial dysfunction that plays a central role in the pathogenesis of micro- and macrovascular diseases, including DCM. It may also increase pro-inflammatory and pro-coagulant factors expression and induce apoptosis [5]. Nowadays, there are many experimental and clinical evidences which confirm the benefits of antioxidant therapies in the prevention and treatment of diabetic complications [6].

* The manuscript was performed in accordance with the scientific theme of the biochemical research laboratory in the SI «V. Danilevsky Institute for Endocrine Pathology Problems of the NAMS of Ukraine» «The determination of mitochondrial dysfunction in the development of diabetic cardiomyopathy and the possibility of correction with natural antioxidants», (state registration №00119U2134).

Institution, which financed the research: NAMS of Ukraine.

The author assume responsibility for the published work.

The author guarantee absence of competing interests and their own financial interest when carrying out the research and writing the article.

The manuscript was received by the editorial staff 29.03.2021. 
Recently the attention has focused on the researches of bioactive molecules contained in foods, which are characterized by fewer side effects in comparison with pharmacological therapies and can be useful in the treatment of T2DM. Dietary flavonoids have shown potential in the reduction of oxidative stress-induced tissue damage through their modulatory effects of intracellular signaling pathways [7].

Quercetin (Q) (3,5,7,3'4'-pentahydroxy flavon) is one of the most promising compounds for disease prevention. $Q$ possesses a wide range of multiple activities: anti-diabetic, antiproliferative, anti-atherosclerotic, antioxidant, anti-inflammatory, anti-thrombotic, anti-apoptotic and other effects [7]. These evidences confirm the perspectives of future researches of $Q$ as a potential therapeutic agent for the treatment of T2DM complications.

The aim of this study was to assess the effects of quercetin on the functional state of cardiovascular system and haemostasis in diabetic rats.

\section{MATERIALS AND METHODS}

The present study was approved by the bioethics committee of the V. Danilevsky Institute of Endocrine Pathology Problems, National Academy of Medical Sciences of Ukraine (Kharkiv, Ukraine) and performed in accordance with the European Convention for the Protection of Vertebrate Animals Used for Experimental and Other Scientific Purposes (Strasbourg, 1986).

The animal model of type 2 diabetes induced by a high-caloric diet, combined with multiple low-dose streptozotocin (STZ) injections, was used. The control intact groups $(\mathrm{n}=10)$ were fed a standard diet ad libitum during 14 weeks. The experimental groups ( $\mathrm{n}=20$ ) were fed the high-caloric diet, containing $16 \%$ fat, $28 \%$ carbohydrates, $6 \%$ proteins for 14 weeks. All groups had free access to water. In four weeks, rats in the experimental group were injected intraperitoneally with small doses of STZ $(25 \mathrm{mg} / \mathrm{kg}$ body weight) twice per week [8].

All diabetic animals were divided into three groups: diabetic group treated with solvent and diabetic rats treated with $\mathrm{Q}$ (in dose 10 and
$50 \mathrm{mg} / \mathrm{kg} /$ day per os) for 8 weeks after diabetes induction.

Tail blood glucose levels were measured using a glucose analyser (Exan-G, Analita, Vilnius, Republic of Lithuania).

At the end of the study electrocardiograms were recorded in leads II using the electrocardiography method. The mean R-R, Q-T, $\mathrm{P}-\mathrm{Q}, \mathrm{QRS}, \mathrm{T}-\mathrm{P}$ intervals and the amplitude and duration of $\mathrm{T}, \mathrm{P}$ and $\mathrm{R}$ waves were calculated.

Fibrinogen concentration and induced euglobulin fibrinolysis time (FT) were measured in plasma using reagent kits «Technology-Standard», Russia for determination of coagulation hemostasis.

Data normality were rated using the Shapiro-Wilk test, and all normally distributed data are expressed as the means \pm standard error of the mean (SEM). Group comparisons of quantitative variables were performed by one-factor analysis of variance (ANOVA). The Newman-Keuls test was used for multiple comparisons of the groups. Values were considered significant at $\mathrm{p}<0.05$.

\section{RESULTS AND DISCUSSION}

As shown in Table 1, the basal glucosae level in diabetic rats was significantly higher in comparison with control rats. There was no significant difference in the basal hyperglycemia between diabetic rats and those treated with $\mathrm{Q}$ (Table 1).

In our study T2DM caused the development of pathologically accelerated rhythm and sinus tachycardia in experimental animals, as indicated by the shortening of R-R intervals and an increase in the heart rate in comparison with intact control group. Q in dose $10 \mathrm{mg} / \mathrm{kg}$ b.w. did not affect these parameters, however, in dose $50 \mathrm{mg} / \mathrm{kg}$ bjdy weight led to the prolongation of $\mathrm{R}-\mathrm{R}$ intervals and prevented the tachycardia progress (Table 1).

It has been established that T2DM leads to the prolongation of electrical systole in experimental animals, as evidenced by an increasing of the total length Q-T intervals, compared to 
Impact of quercetin on basal glucosae level, heart rate, duration of R-R, Q-T, P-Q, QRS and T-P intervals, amplitude and duration of $T, P$ and $R$ waves in diabetic rats, $\left(\bar{X} \pm S_{\bar{X}}\right), n=6$

\begin{tabular}{c|c|c|c|c}
\hline Indexes & Control group & Diabetes & Diabetes + Q & Diabetes + Q \\
\hline Dose, mg/kg & & & 10 & 50 \\
\hline Basal glucosae level, mmol/l & $3,75 \pm 0,08$ & $9,00 \pm 1,19^{\mathrm{a}}$ & $8,50 \pm 1,12^{\mathrm{a}}$ & $8,30 \pm 0,61^{\mathrm{a}}$ \\
\hline R-R interval, msec & $125.0 \pm 2,4$ & $115.3 \pm 2.1^{\mathrm{a}}$ & $116.0 \pm 2.6^{\mathrm{a}}$ & $124.0 \pm 2.1^{\mathrm{bc}}$ \\
\hline Heart rate, sec ${ }^{-1}$ & $481.2 \pm 9,4$ & $522.1 \pm 10.7^{\mathrm{a}}$ & $500.7 \pm 6.2^{\mathrm{a}}$ & $491.4 \pm 10.4^{\mathrm{bc}}$ \\
\hline Q-T interval, msec & $50.4 \pm 2,9$ & $64.8 \pm 3.4^{\mathrm{a}}$ & $64.4 \pm 2.1^{\mathrm{a}}$ & $66.8 \pm 3.4^{\mathrm{a}}$ \\
\hline P-Q interval, msec & $40.4 \pm 1,4$ & $40.0 \pm 0,6$ & $38.8 \pm 1,0$ & $43.0 \pm 1,4$ \\
\hline QRS interval, msec & $30.8 \pm 1,1$ & $30.6 \pm 1,3$ & $31.8 \pm 1,0$ & $29.8 \pm 1,2$ \\
\hline T-P interval, msec & $25.2 \pm 2,5$ & $15.6 \pm 1.6^{\mathrm{a}}$ & $20.2 \pm 1.2^{\mathrm{ab}}$ & $21.0 \pm 1.3^{\mathrm{ab}}$ \\
\hline Amplitude of T-wave, $\mathrm{mV}$ & $0.057 \pm 0,004$ & $0.080 \pm 0.010^{\mathrm{a}}$ & $0.105 \pm 0.004^{\mathrm{a}}$ & $0.082 \pm 0.003^{\mathrm{a}}$ \\
\hline Duration of T-wave, sec & $0.021 \pm 0,002$ & $0.039 \pm 0.002^{\mathrm{a}}$ & $0.028 \pm 0.002^{\mathrm{ab}}$ & $0.029 \pm 0.003^{\mathrm{ab}}$ \\
\hline Amplitude of P-wave, $\mathrm{mV}$ & $0.048 \pm 0,004$ & $0.046 \pm 0,005$ & $0.037 \pm 0.005$ & $0.042 \pm 0,005$ \\
\hline Duration of P-wave, sec & $0.026 \pm 0,001$ & $0.023 \pm 0,001$ & $0.022 \pm 0,002$ & $0.023 \pm 0,001$ \\
\hline Amplitude of R-wave, $\mathrm{mV}$ & $0.184 \pm 0,009$ & $0.186 \pm 0,011$ & $0.177 \pm 0.011$ & $0.188 \pm 0,011$ \\
\hline Duration of R-wave, sec & $0.022 \pm 0,002$ & $0.023 \pm 0,002$ & $0.025 \pm 0,001$ & $0.027 \pm 0,001$ \\
\hline
\end{tabular}

Note:

Data are shown as mean \pm standard error of the mean (SEM).

a significant versus match control group $(p<0.05)$,

b significant versus group «Diabetes» $(p<0.05)$,

c $\quad$ significant versus group «Diabetes $+Q, 10 \mathrm{mg} / \mathrm{kg}$ » $(\mathrm{p}<0.05)$.

control group. However, Q in both doses did not change the action potential duration in diabetic rats (Table 1).

It was found that P-Q intervals reflected the time required for depolarization of the atria and conduction of electrical impulses through the atrioventricular node, bundle of $\mathrm{His}$ and branches, as well as QRS intervals, which is a sign of the depolarization of the ventricular complex, are similar to electrocardiograms data of control animals. Q did not affect the speed of signals through the longest part of the heart conduction system and ventricles (Table 1).

It is known that the early stage of diabetic cardiomyopathy is associated with a range of metabolic abnormalities and with abnormalities in diastolic function [9].

Our results have shown that T2DM promotes the development of diastolic dysfunction in experimental animals. Our study clearly points out the signs of diastolic dysfunction such as shortening of diastolic T-P interval and an increase of amplitude and duration of the $\mathrm{T}$ waves, which reflects the processes of ventricu- lar myocardial repolarization, in comparison with control rats (Table 1).

At the same time, the ECG analysis shown that $\mathrm{Q}$ in both doses significantly increases the duration of the heart electrical inactivity period compared with the diabetic group, which indicates a positive effect of $\mathrm{Q}$ for the myocardial renewal (Table 1).

It was established that $\mathrm{Q}$ in dose-independently manner shortens the $\mathrm{T}$ waves, which indicate its positive effect on the restoration of ventricular repolarization, which may be explained by inhibition of ischemic processes in the myocardium (Table 1).

The findings are referred to clinical and experimental data on the cardioprotective effect of $\mathrm{Q}$, which may be associated with preventing of left ventricular hypertrophy and diastolic dysfunction [10-13].

It has been established that duration of the $\mathrm{P}$-wave and $\mathrm{R}$-wave doesn't change in any experimental groups (Table 1).

The data of this study confirmed the presence of the inhibitory effect of $Q$ on the deve- 
Impact of quercetin on fibrinogen concentration and induced euglobulin fibrinolysis time in diabetic rats, $\left(\overline{\mathrm{X}}_{ \pm} \mathrm{S}_{\overline{\mathrm{X}}}\right), \mathbf{n}=10$

\begin{tabular}{c|c|c|c|c}
\hline Indexes & Control group & Diabetes & Diabetes + Q & Diabetes + Q \\
\hline Dose, mg/kg & & & 10 & 50 \\
\hline $\begin{array}{c}\text { Fibrinogen } \\
\text { concentration, g/L }\end{array}$ & $1.65 \pm 0,11$ & $2.29 \pm 0.19^{\mathrm{a}}$ & $1.55 \pm 0.06^{\mathrm{b}}$ & $1.50 \pm 0.08^{\mathrm{b}}$ \\
\hline FT, min & $7.75 \pm 0,61$ & $14.29 \pm 1.19^{\mathrm{a}}$ & $9.55 \pm 1.06^{\mathrm{b}}$ & $8.50 \pm 0.88^{\mathrm{b}}$ \\
\hline
\end{tabular}

Note:

Data are shown as mean \pm standard error of the mean (SEM).

a significant versus match control group $(p<0.05)$,

b significant versus group «Diabetes» $(p<0.05)$.

lopment of myocardial diastolic dysfunction in rats with T2DM.

Beside the higher risk of development CVD, T2DM has been recognized as an independent risk factor of atherothrombosis which can result in the progression of atherosclerosis, sudden cardiac death, myocardial infarction and stroke [14].

Clinical and experimental researches have shown that Q manifests anti-inflammatory and antioxidative properties which provide its antithrombogenic and anticoagulant activity. It was indicated that $Q$ inhibits the enzymatic activity of thrombin and suppress fibrin clot formation and blood clotting due to their selective binding to the thrombus wall, as well as due to its antioxidant properties that help restore biosynthesis and action of endothelial prostacyclin-endothelium and endothelium [15]. In addition, $\mathrm{Q}$ reduces platelet hyperfunction due to inhibition of phosphorylation-dependent cellular signaling pathways [16].

It is known that the high plasma levels of coagulation indexes, including fibrinogen, are associated with an elevated risk of coronary thrombotic events [17]. In our study T2DM caused an increase in fibrinogen concentration in plasma of experimental animals in comparison with intact control group (Table 2). However, Q in both doses decreased fibrino- gen levels compared to diabetic rats (Table 2), which confirms the positive effect of $\mathrm{Q}$ on the processes of coagulations.

Our results are corresponded with the date of other studies in which the use of apple juice rich in $\mathrm{Q}$ decreases concentration of triglycerides, fibrinogen and vitamin K-dependent coagulation factor (factor VII) in rabbits receiving a high cholesterol diet [18]. Q due to its antiinflammatory and antioxidative properties may modulate the prothrombotic and inflammatory environment typically found in atherothrombotic disease [19].

Altered level of fibrinogen can modulate plasma clot lysis and thereby increases thrombosis risk [20].

Our data have shown that the fibrin molecules have undergone structural alterations, as indicated by two times increasing of FT in comparison with control group. Q, independently of dose, decreased the time of thrombolysis which confirmed its significant thrombolytic activity potential (Table 2).

Thus, the ability of $\mathrm{Q}$ to decrease fibrinogen level and reduce the fibrinolysis time, both of which are associated with an elevated risk of coronary thrombotic events, allows considering it as a potential therapy for the treatment of thrombotic disorders.

\section{CONCLUSIONS}

1. Our results demonstrated that $\mathrm{Q}$ in dose $50 \mathrm{mg} / \mathrm{kg}$ body weight prevents the tachycardia progress and, independently of dose, inhibits the development of myocardial diastolic dysfunction in rats with type 2 diabetes as evidenced by an increasing the dura- tion of heart rest period and the restoration of ventricular repolarization processes.

2. $\mathrm{Q}$ in both doses normalizes the fibrinogen levels and the time of thrombolysis in the serum of diabetic animals, which confirms its antithrombotic properties. 
3. We conclude that cardioprotective and antithrombotic effects of $Q$ justify its perspective as an agent to prevent and management of diabetic cardiovascular complications, particularly in individuals with high risk of thrombotic events.

\section{REFERENCES}

1. IDF. Diabetes Atlas. $9^{\text {th }}$ ed, Brussels, 2019: 150 p.

2. Tan Y, Zhang Z, Zheng Ch, et al. Nature Rev Cardiol 2020; 17: 585-607.

3. Patti G, Cavallari I, Andreotti F, et al. Nature Rev Cardiol 2019; 16: 113-130.

4. Sobczak AIS, Stewart AJ. Int J Mol Sci 2019; 20(24): 6345 .

5. Kaur R, Kaur M, Singh J. Cardiovasc Diabetol 2018; 17: 8.: https://doi.org/10.1186/ s12933-018-0763-3.

6. Dal St, Sigrist S. Diseases 2016; 4: 24. https://doi.org/10. 3390/diseases4030024.

7. Carrizzo A, Izzo C, Forte M, et al. Int J Mol Sci 2020; 21(22): 8706.

8. Lin S, Yang J, Wu G, et al. J Biomed Sci 2010; 17(1): S46.

9. Athithan L, Gulsin GS, McCann GP, et al. World $J$ Diabetes 2019; 10(10): 490-510.

10. Micek A, Godos J, Del Rio D, et al. Mol Nutr Food Res 2021; 65(6): 10. https://doi.org/10.1002/mnfr.202001019.

11. Williamson G, Sheedy K. Nutrients 2020; 12(10): 3135.
12. Mirsafaei L, Reiner $\mathfrak{h}$, Shafabakhsh R, et al. Plant Foods for Human Nutrition 2020; 75: 307-315.

13. Castillo RL, Herrera EA, Gonzalez-Candia A, et al. Oxidative MedCell Longevity 2018: 9. https://doi.org/10. 1155/2018/7239123.

14. Marthn-Timyn I, Sevillano-Collantes C, Segura-Galindo A, et al. World J Diabetes 2014; 5(4): 444-470.

15. Choi J, Kim K, Kim S. J Biochem Mol Toxicol 2016; 30(11): 548-558.

16. Mosawy S. Food and Public Health 2015; 5(1): 1-9.

17. Soma P, Pretorius E. Cardiovasc Diabetol 2015; 31(14): 96.

18. Setorki M, Asgary S, Eidi A, et al. Lipids Health Dis 2009; 8: 39 .

19. Patel RV, Mistry BhM, Shinde SK, et al. Eur J Med Chem 2018; 155(15): 889-904.

20. Kearney K, Tomlinson D, Smith K, et al. Cardiovasc Diabetol 2017; 16(34): 14. https://doi.org/10.1186/s12933017-0515-9.

\section{THE IMPACT OF QUERCETIN ON THE FUNCTIONAL STATE OF CARDIOVASCULAR SYSTEM AND HEMOSTASE IN RATS WITH TYPE 2 DIABETES MELLITUS

\author{
Ivanova $\mathbf{O}$. V.
}

SI «V. Danilevsky Institute for Endocrine Pathology Problems of the NAMS of Ukraine», Kharkiv, Ukraine

ivolga3006@ukr.net

Type 2 diabetes mellitus (T2DM) increases the risk for atherosclerotic cardiovascular disease and other cardiovascular complications such as cardiac arrhythmias, heart failure, and thrombotic events. Quercetin (Q) possesses a wide range of multiple activities: anti-diabetic, anti-proliferative, anti-atherosclerotic, antioxidant, anti-inflammatory, anti-thrombotic, anti-apoptotic effects and is regarded as a candidate for the role of cardiovascular complications protecting agent. The aim of this study was to assess the effects of $Q$ on the functional state of cardiovascular system and haemostasis in diabetic rats. T2DM was induced in Wistar rats by a high-caloric diet during 14 weeks combined with intraperitoneal injections of $25 \mathrm{mg} / \mathrm{kg}$ streptozotocin twice per week. All diabetic animals were divided into three groups: treated with solvent and with $\mathrm{Q}$ (in dose 10 and $50 \mathrm{mg} / \mathrm{kg} /$ day per os) for 8 weeks after diabetes induction. Fibrinogen concentration and induced euglobulin fibrinolysis time were measured in plasma using reagent kits. Electrocardiograms were recorded in leads II. It was established that Q in dose $50 \mathrm{mg} / \mathrm{kg}$ bjdy weight prevents in the formation of sinus tachycardia in experimental animals. In addition, Q in both doses inhibits the development of myocardial diastolic dysfunction, which was confirmed by prolongation of T-P interval and a decrease of duration of the T wave in comparison with diabetic rats. Q in both doses restorated the processes of coagulations and fibrinolysis, as indicated by a decrease of fibrinogen levels and the time of thrombolysis compared to diabetic rats. Conclusions. Q, independently of dose, inhibits the development of myocardial diastolic dysfunction and reduces prothrombotic potential in rats with type 2 diabetes, which may ameliorate diabetic cardiovascular risk. This data justify the perspective of $\mathrm{Q}$ for the prevention and management of cardiovascular complications in patients with type 2 diabetes.

Key words: quercetin, type 2 diabetes, functional state of the cardiovascular system, coagulation hemostasis, rats. 


\title{
ВПЛИВ КВЕРЦЕТИНУ НА ФУНКЦІОНАЛЬНИЙ СТАН СЕРЦЕВО-СУДИННОЇ СИСТЕМИ І ГЕМОСТАЗ У ЩУРІВ ІЗ ЦУКРОВИМ ДІАБЕТОМ 2 ТИПУ
}

\author{
Іванова О. В.
}

ДУ “Інститут проблем ендокринної патологї ім. В.Я. Данилевського» НАМН Украӥни, м. Харків, Україна ivolga3006@ukr.net

Цукровий діабет (ЦД) 2 типу збільшує ризик розвитку атеросклеротичних серцево-судинних захворювань та інших кардіо-васкулярних ускладнень, таких як аритмії, серцева недостатність та тромботичні події. Кверцетин $\left(\kappa_{\mathrm{B}}\right)$ володіє широким спектром активностей: антидіабетичним, антипроліферативним, антиатеросклеротичним, антиоксидантним, протизапальним, антитромбічним, антиапоптотичним ефектом і розглядаеться як перспективний фрармакологічний агент для попередження серцево-судинних ускладнень. Метою даного дослідження було оцінити вплив Кв на функціональний стан серцево-судинної системи та гемостаз у діабетичних щурів. ЦД 2 типу індукували у щурів популяції Wistar висококалорійної дієтою протягом 14 тижнів в поеднанні з двома внутрішньочеревними ін'екціями стрептозотоцину в дозі 25 мг/кг через тиждень. Усі діабетичні тварини були розділені на три групи: щури, які отримували розчинник або $\kappa_{\text {в }}$ у двох дозах (10 та 50 мг/кг/день перорально) протягом 8 тижнів після індукції діабету. Концентрацію фібриногену та індукований час фібринолізу вимірювали у плазмі за допомогою наборів реагентів. В кінці дослідження електрокардіограми реестрували у II-му відведенні від кінцівок. Встановлено, що Кв в дозі 50 мг/кг м.т. запобігає розвитку синусової тахікардії у діабетичних тварин. Крім того, Кв в обох дозах гальмував прогресування діастолічної дисфункції міокарда, що підтверджувалося подовженням інтервалу Т-Р та зменшенням тривалості зубця Т в порівнянні з діабетичними щурами. Введення Кв в обох дозах супроводжувалося відновленням процесів коагуляції та фрібринолізу, про що свідчило зниження рівня фрібриногену та часу тромболізису порівняно з діабетичною групою. Кверцетин, незалежно від дози, пригнічує розвиток діастолічної дисфрнкції міокарда та зменшуе протромбічний потенціал у щурів із ЦД 2 типу, що може знизити діабетичний кардіо-васкулярний ризик. Отримані дані обірунтовують перспективність використання Кв для профілактики та лікування серцево-судинних ускладнень у пацієнтів з ЦД 2 типу.

К л юч о в с лов а: кверцетин, цукровий діабет 2 типу, функціональний стан серцево-судинної системи, коагуляційний гемостаз, щури. 